\title{
A Study on Profile Characteristics of Farmers on No-Till Maize Technology
}

\author{
P. Vara Prasad ${ }^{1 *}$, B. Mukunda Rao ${ }^{1}$, G. Sivanarayana ${ }^{1}$ and Ch. Pulla Rao ${ }^{2}$ \\ ${ }^{1}$ Department of Agricultural Extension, Acharya N G Ranga Agricultural University, \\ Agricultural College, Bapatla, Guntur-522101, Andhra Pradesh, India \\ ${ }^{2}$ Department of Agronomy, Acharya N G Ranga Agricultural University, Agricultural College, \\ Bapatla, Guntur-522101, Andhra Pradesh, India \\ *Corresponding author
}

A B S T R A C T

Keywords

No-till technology,

Maize farmers and profile characteristics

Article Info

Accepted:

12 March 2018

Available Online:

10 April 2018
The present study was conducted in three mandals of Guntur district of Andhra Pradesh to study the profile characteristics of no-till maize farmers. Total 120 respondents were randomly selected for the study and interviewed. Most of the respondents were middle aged (45.00\%), had high school education $(24.17 \%)$, had small land holding $(30.83 \%)$, with $4-6$ years of farming experience in no-till maize cultivation $(46.67 \%)$ followed by medium levels of annual income (62.50\%), social participation $(55.83 \%)$, mass media exposure $(60.83 \%)$, extension contact $(58.33 \%)$, innovativeness $(59.17 \%)$, scientific orientation $(65.83 \%)$, economic motivation $(72.50 \%)$ and risk orientation $(75.00 \%)$.

\section{Introduction}

Maize is the third most important cereal crop in India after rice and wheat. Rice (Oryza sativa L.) - Maize (Zea mays L.) is one of the pre-dominant cropping system of both command and non-command areas of Andhra Pradesh. The concept of zero-tillage is gaining momentum in traditional areas under ricemaize sequence. This technique aids in overcoming planting difficulties in rice fallow, reduce weed competition and improves fertilizer and water use efficiency and reduces the capital investment in machinery for land preparations and intercultural operations and improve maize yields. In addition to this severe YMV problem in black gram also forced the farmers to switch over to nontraditional crop like maize in rice-fallows as an alternative to black gram.

This technology was adopted by the farmers of Guntur district themselves due to nonprofitability of paddy-pulse crop sequence. Due to concentration of all efforts, on enhancement of productivity of maize, cost of cultivation of maize has drastically increased and leads to less net profit for the farmers. In addition to that, soil health has deteriorated due to over usage of fertilizers and pesticides. 
The existing situation had prevailed to study the profile characteristics of no-till maize farmers.

\section{Materials and Methods}

The study was conducted in Guntur district because of its largest area and production under maize crop in all the districts of Andhra Pradesh. From the selected district three mandals were selected purposively. Then from each of the selected mandal, four villages were selected based on random sampling. Thus in all twelve villages were selected. Respondents were further selected based on proportionate random sampling thus constituting a sample size of 120 respondents. The data were collected personally with the help of an structured interview schedule.

\section{Results and Discussion}

\section{Age}

It could be inferred from the table 1 that majority (45.00\%) of the no-till maize farmers belonged to middle age category, followed by the rest belonged to old age category (35.83\%) and young age category (19.17\%).

This might be due to lack of opportunity to change their profession among middle and old age making them to become loyal to their existing profession, whereas larger portion of the younger generation didn't prefer agriculture as they turned towards industries, information technology and management.

\section{Education}

A glance of the table 1 could be seen that majority $(24.17 \%)$ of the respondents were high school education followed by middle school $(18.33 \%)$, primary school $(15.83 \%)$, illiterate (13.33\%), intermediate education (11.67\%), functionally literate $(10.00 \%)$ and graduation and above $(6.67 \%)$.
The probable reason for majority of farmers to be in high school might be due to lack of awareness among elders in the village about education and lack of encouragement from their family members for further continuance of their education, non-availability of educational facilities in the villages and poor economic condition of the farmers.

\section{Land holding}

On perusal of table 1 reported that majority $(30.83 \%)$ of no till maize farmers belonged to small land holdings followed by marginal (25.00\%), semi-medium (21.67\%), medium $(14.17 \%)$, landless $(5.00 \%)$ and large farmers $(3.33 \%)$.

The possible reason might be that in the recent times most of the families are of nuclear system and joint family system is gradually fading away.

This resulted in fragmentation of land holdings among the family members. Hence, there is a need to concentrate on small and marginal no-till maize farmers in transfer of technology.

\section{Farming experience in no-till maize cultivation}

The table 1 describes that majority (46.67\%) of the farmers have 4 to 6 years of farming experience in no-till maize cultivation followed by 22.50 per cent with 7 to 9 years, 15.00 per cent with 1 to 3 years, 10.00 per cent with $10-12$ years and only 05.83 per cent of farmers with 13 to 15 years of farming experience in no-till maize cultivation.

The probable reason could be that cultivation of no-till maize was started during 2000 and gradually farmers are shifted from rice-fallow pulses to no-till maize due to non-profitability of paddy-relay pulses cropping pattern. 
Table.1 Distribution of no-till maize farmers according to their profile characteristics

\begin{tabular}{|c|c|c|c|c|}
\hline \multirow[t]{2}{*}{ S. No. } & \multirow[t]{2}{*}{ Independent variables } & \multirow[t]{2}{*}{ Category } & \multicolumn{2}{|c|}{ Respondents } \\
\hline & & & $\mathbf{F}$ & $\mathbf{P}$ \\
\hline 1. & Age & $\begin{array}{l}\text { Young age }(<35 \text { years }) \\
\text { Middle age ( } 35 \text { to } 58 \text { years }) \\
\text { Old age }(>58 \text { years })\end{array}$ & $\begin{array}{l}23 \\
54 \\
43\end{array}$ & $\begin{array}{l}19.17 \\
45.00 \\
35.83\end{array}$ \\
\hline 2. & Education & $\begin{array}{l}\text { Illiterate } \\
\text { Functionally literate } \\
\text { Primary school } \\
\text { Middle school } \\
\text { High school } \\
\text { Intermediate Education } \\
\text { Graduation and above }\end{array}$ & $\begin{array}{l}16 \\
12 \\
19 \\
22 \\
29 \\
14 \\
8\end{array}$ & $\begin{array}{l}13.33 \\
10.00 \\
15.83 \\
18.33 \\
24.17 \\
11.67 \\
06.67\end{array}$ \\
\hline 3. & Land Holding & $\begin{array}{l}\text { Landless (no land) } \\
\text { Marginal ( } 0.1 \text { to } 1.0 \text { hectare) } \\
\text { Small (1.1 to } 2.0 \text { hectare }) \\
\text { Semi-Medium }(2.1 \text { to } 4.0 \text { hectare }) \\
\text { Medium }(4.1 \text { to } 10.0 \text { hectare }) \\
\text { Large }\left(10.0^{+} \text {hectare }\right)\end{array}$ & $\begin{array}{c}6 \\
30 \\
37 \\
26 \\
17 \\
4\end{array}$ & $\begin{array}{l}05.00 \\
25.00 \\
30.83 \\
21.67 \\
14.17 \\
03.33\end{array}$ \\
\hline 4. & $\begin{array}{l}\text { Farming Experience in } \\
\text { no-till maize cultivation }\end{array}$ & $\begin{array}{l}1-3 \text { years } \\
4-6 \text { years } \\
7-9 \text { years } \\
10-12 \text { years } \\
12-15 \text { years }\end{array}$ & $\begin{array}{c}18 \\
56 \\
27 \\
12 \\
7\end{array}$ & $\begin{array}{l}15.00 \\
46.67 \\
22.50 \\
10.00 \\
05.83\end{array}$ \\
\hline 5. & $\begin{array}{l}\text { Annual Income } \\
\bar{X}=4.14 \\
\sigma=1.68\end{array}$ & $\begin{array}{l}\text { Low }(<2.46) \\
\text { Medium }(2.47 \text { to } 5.82) \\
\text { High }(>5.82)\end{array}$ & $\begin{array}{l}21 \\
75 \\
24\end{array}$ & $\begin{array}{l}17.50 \\
62.50 \\
20.00\end{array}$ \\
\hline 6. & $\begin{array}{l}\text { Social Participation } \\
\begin{array}{l}\bar{X}=2.44 \\
\sigma=1.15\end{array}\end{array}$ & $\begin{array}{l}\text { Low }(<1.29) \\
\text { Medium }(1.30 \text { to } 3.59) \\
\text { High }(>3.59)\end{array}$ & $\begin{array}{l}30 \\
67 \\
23\end{array}$ & $\begin{array}{l}25.00 \\
55.83 \\
19.17\end{array}$ \\
\hline 7. & $\begin{array}{l}\text { Mass Media Exposure } \\
\bar{X}=14.64 \\
\sigma=2.44\end{array}$ & $\begin{array}{l}\text { Low }(<12.20) \\
\text { Medium }(12.21 \text { to } 17.08) \\
\text { High }(>17.08)\end{array}$ & $\begin{array}{l}29 \\
73 \\
18\end{array}$ & $\begin{array}{l}24.17 \\
60.83 \\
15.00\end{array}$ \\
\hline 8. & $\begin{array}{l}\text { Extension Contact } \\
\bar{X}=30.68 \\
\sigma=4.56\end{array}$ & $\begin{array}{l}\text { Low }(<26.12) \\
\text { Medium }(26.13 \text { to } 35.24) \\
\text { High }(>35.24)\end{array}$ & $\begin{array}{l}30 \\
70 \\
20\end{array}$ & $\begin{array}{l}25.00 \\
58.33 \\
16.67\end{array}$ \\
\hline 9. & $\begin{array}{l}\text { Innovativeness } \\
\bar{X}=18.53 \\
\sigma=2.12\end{array}$ & $\begin{array}{l}\text { Low }(<16.41) \\
\text { Medium }(16.42 \text { to } 20.65) \\
\text { High }(>20.65)\end{array}$ & $\begin{array}{l}27 \\
71 \\
22\end{array}$ & $\begin{array}{l}22.50 \\
59.17 \\
18.33\end{array}$ \\
\hline 10. & $\begin{array}{l}\text { Scientific Orientation } \\
\bar{X}=19.56 \\
\sigma=3.29\end{array}$ & $\begin{array}{l}\text { Low }(<16.27) \\
\text { Medium }(16.28 \text { to } 22.85) \\
\text { High }(>22.85)\end{array}$ & $\begin{array}{l}24 \\
79 \\
17\end{array}$ & $\begin{array}{l}20.00 \\
65.83 \\
14.17\end{array}$ \\
\hline 11. & $\begin{array}{l}\text { Economic Motivation } \\
\bar{X}=25.18 \\
\sigma=1.87\end{array}$ & $\begin{array}{l}\text { Low }(<23.31) \\
\text { Medium }(23.32 \text { to } 27.05) \\
\text { High }(>27.05)\end{array}$ & $\begin{array}{l}11 \\
87 \\
22\end{array}$ & $\begin{array}{l}09.17 \\
72.50 \\
18.33\end{array}$ \\
\hline 12. & $\begin{array}{l}\text { Risk Orientation } \\
\bar{X}=15.02 \\
\sigma=1.46\end{array}$ & $\begin{array}{l}\text { Low }(<13.56) \\
\text { Medium }(13.57 \text { to } 16.48) \\
\text { High }(>16.48)\end{array}$ & $\begin{array}{l}17 \\
90 \\
13\end{array}$ & $\begin{array}{l}14.17 \\
75.00 \\
10.83\end{array}$ \\
\hline
\end{tabular}




\section{Annual income}

An over view of the table 1 indicated that 62.50 per cent of the no-till maize farmers had medium level of annual income, followed by rest with high (20.00\%) and low (17.50\%) level of annual income.

This could be due to the fact that majority of the no-till maize farmers being small and marginal that too without any other source of income. But, few had high annual income due to their comparatively good land holding size with additional sources of income as job or business.

\section{Social participation}

It could be comprehended from the table 1 that a majority $(55.83 \%)$ of the no-till maize farmers had medium level of social participation, followed by 25.00 per cent of them with low level and 19.17 per cent of them with high level of social participation.

This trend might be due to, lack of interest and time, non-attractiveness of the activities undertaken by the organizations, lack of more no of organizations in the villages and local politics prevailed in the villages. Extension agencies should encourage the farmers in social participation by helping them to form youth clubs, Commodity Interest Groups (CIG's), Rythu Mitra Groups (RMG's) etc., so that they will get more exposure.

\section{Mass media exposure}

Results furnished in table 1 indicated that majority $(60.83 \%)$ of the no-till maize farmers had medium mass media exposure, followed by 24.17 per cent with low and 15.00 per cent with high mass media exposure.

Thus it could be concluded that sources like newspapers, television programmes and mobiles were regularly utilized by the no-till maize farmers for getting information about no-till maize cultivation practices. The reasons might be due to easy availability, accessibility and credibility attached with these sources.

Surprisingly Information and communication Technologies (ICT's) like cell phones and internet were used occasionally by the farmers. This trend shows the interest of the farmers toward ICT. So the government should provide incentives for establishing internet centres in the rural areas.

\section{Extension contact}

An overview of the table 1 indicated that majority $(58.33 \%)$ of the no-till maize farmers had medium extension contact, followed by those with low $(25.00 \%)$ extension contact. Whereas, only 16.67 per cent of the no-till maize farmers had high extension contact.

The reason might be due to easy accessibility of informal sources and maintenance of good rapport with the friends, relatives, progressive farmers and input dealers. Only less significant of formal sources were contacted by the respondents for getting information related to no-till maize cultivation. This might be due to non-availability of officers in respective offices, because of their preoccupied works like distribution of seeds, attending meetings etc. So the government should fill all the vacancies in the department of agriculture for dissemination of latest technologies to the farming community.

\section{Innovativeness}

The results from table 1 reported that 59.17 per cent of the no-till maize farmers had medium level of innovativeness, followed by rest with low (22.50\%) and high (18.33\%) level of innovativeness. 
This might be due to majority of the no-till maize farmers belonged to medium to low innovativeness was that, as study area being suitable for no-till maize cultivation the imitation of the crop was quite common and majority of the respondents were middle to old aged with high school education, medium level of mass media exposure, extension contact, scientific orientation, economic motivation and risk orientation. The possible reason for high innovativeness may be due to majority of the no-till maize farmers belonged to small and marginal farmers so they have more chance to adopt new technologies and greater scope to contact with extension personnel.

\section{Scientific orientation}

It was evident from the table 1 that majority $(65.83 \%)$ of the no-till maize farmers had medium scientific orientation, followed by those with low (20.00\%) and high (14.17\%) levels of scientific orientation.

This trend might be due to the fact that majority of the no-till maize farmers were middle to old age, high school education with medium level of mass media exposure, extension contact and innovativeness. It may also be due to self-contentment of the no-till maize farmers with the existing technology what they are using.

Hence, the Agriculture department needs to make every effort to deliver the modern technology at a reasonable cost taking the help of government.

\section{Economic motivation}

The table 1 clearly indicated that nearly threefourth $(72.50 \%)$ of the no-till maize farmers had medium level of economic motivation followed by high level (18.33\%) and low level $(09.17 \%)$ of economic motivation.
From the above results it could be inferred that, three fourth of the no-till maize farmers had medium level of economic motivation. This might be due to the common truth that the respondents had the urge for more monetary profit per unit area and naturally that would have motivated the farmers to adopt no-till maize cultivation practices.

\section{Risk orientation}

A glance at the table 1 revealed that 75.00 per cent of the no-till maize farmers had medium level of risk orientation, followed by those with low (14.17\%) and high (10.83\%) levels of risk orientation. Three fourth of the no-till maize farmers were found to have medium level of risk orientation.

This might be due to majority of the no-till maize farmers belonging to middle to old age with high level of education, small to marginal farmers with medium mass media exposure, extension contact, social participation, innovativeness and economic motivation categories. Farmers could not venture to take risk in adopting more recommended and improved practices unless demonstrated their performance.

\section{References}

Ambedkar, D. 2010. A study on extent of adoption and constraints faced by the bengalgram farmers in Prakasam district of Andhra Pradesh. M. Sc. (Ag.) Theis. Acharya N G Ranga Agricultural University, Hyderabad, India.

Arathy, B. 2011. Constraint analysis of rice farmers of Trissur district of Kerala. $M$. Sc. (Ag) Thesis, Acharya N G Ranga Agricultural University, Hyderabad, India.

Ganesh Kumar, P., Jyosthna, M.K and Lakshmi Reddy, P. 2013. Knowledge and extent of adoption of improved 
practices of Chickpea through KVK interventions. Journal of Research Acharya N G Ranga Agricultural University, Hyderabad, India. 41 (3): 58-63.

Gowda, A.T., Ramesh Babu, C.H., Ram Naidu, G.B.M and Srinivasa Rao, V. 2011. Profile characteristics of sugarcane growers in Mandhya district of Karnataka. The Andhra Agricultural Journal. 58 (2): 123-126.

Kalyan, V. N. 2011. Impact analysis of groundnut production technologies in Chittoor district of Andhra Pradesh. M.Sc. (Ag.) Thesis. Acharya N G Ranga Agricultural University, Hyderabad, India.

Kumar, S., Sharma, G and Yadav, V.K. 2013. Factors influencing entrepreneurial behaviour of vegetable growers. Indian Research Journal of Extension Education. 13 (1): 16-19.

Mandal, B.K and Deepak, D. E. 2010. Socio economic profile and communication behavior of paddy growers - A study of Banka district. Journal of
Communication Studies. 25 (4):121123.

Nrusimha Kalyan, V., Satya Gopal, P and Prasad, S.V. 2012. Profile characteristics of groundnut farmers in Chittoor district of Andhra Pradesh. The Andhra Agricultural Journal. 59 (2): 332-335.

Painkra, S.K., Dev, C.M and Mandal, B.K. 2010. Information sources of tribal rice growers of Bastar district of Chhattisgarh. Journal of Communication Studies. 28 (9):135139.

Singh, P., Jat, H.L and Sharma, S.K. 2011. Association of socio-economic attributes with adoption of cluster bean technologies. Indian Research Journal of Extension Education. 11 (2): 37-41.

Tidke, G.R., Rathod, M.K and Mandve, R.P. 2012. Knowledge and adoption of farmers about the management of pod borer complex in pigeon pea. International Journal of Extension Education. 8: 71-76.

\section{How to cite this article:}

Vara Prasad, P., B. Mukunda Rao, G. Sivanarayana and Pulla Rao, Ch. 2018. A Study on Profile Characteristics of Farmers on No-Till Maize Technology. Int.J.Curr.Microbiol.App.Sci. 7(04): 1696-1701. doi: https://doi.org/10.20546/ijcmas.2018.704.192 